\title{
Moral Recovery and Ethical Leadership
}

\author{
John G. Cullen ${ }^{1} \mathbb{0}$
}

Received: 7 February 2019 / Accepted: 15 October 2020 / Published online: 22 October 2020

(c) Springer Nature B.V. 2020

\begin{abstract}
Research on ethical leadership generally falls into two categories: one celebrates individual leaders and their 'authentic' personalities and virtuous stewardship of organizations; the other decries toxic leaders or individuals in positions of power who exhibit 'dark' personality traits or dubious morals. Somewhere between these extremes, leadership is 'done' by imperfect human beings who try to avoid violating their own ethical standards while at the same time navigating the realities of social and organizational life. This paper discusses the concept of 'Moral Recovery' as an ethical leadership process that begins in moral failure, but enables eventual personal, organizational, and social change. It builds on the concept of 'Moral Injury' from the work of the psychiatrist Johnathan Shay and refers to the experiences of armed service personnel traumatized by experiences where either they, or their leaders, violated their own values. 'Morally injured' parties recover their sense of wellbeing through engaging with restorative communal actions which address the social causes of unethical practices. The process of Moral Recovery requires restorative communal actions which address the social causes of unethical practices. This paper will outline the concept of 'Moral Recovery' as a form of practical ethical leadership and change. It will illustrate its relevance to ethical leadership practice with reference to one high-profile case; Ray Anderson of Interface. As this paper is primarily conceptual, avenues for future research are identified, and implications for teaching practice are discussed.
\end{abstract}

Keywords Moral recovery $\cdot$ Ethical leadership $\cdot$ Moral injury $\cdot$ Communal responses $\cdot$ Social action $\cdot$ Reparation $\cdot$ Guilt

\section{Introduction}

The idea of being 'sick' or becoming 'injured' as a critical step in personal, organizational, and transformational leadership has received little treatment in the ethical leadership literature. Instead of assuming that leaders are either ethical or destructive, this article proposes that the process of realizing that one has unintentionally violated personal ethical standards and caused injury or harm to another individual, or group of individuals, can be recovered from by creating social, organizational, or environmental benefits. The theoretical foundation for this process, 'Moral Recovery,' builds on the work of the American psychiatrist Johnathan Shay. Shay described armed service personnel traumatized by experiences where either they, or their leaders, violated their own values as being 'Morally Injured.' Morally Injured people can recover their sense of wellbeing through engaging

John G. Cullen

john.g.cullen@mu.ie

1 Maynooth University School of Business, Maynooth

University, Maynooth, Co. Kildare, Ireland with restorative communal actions which address the social causes of unethical practices.

This paper proceeds as follows. First, reviews of research on the concept of ethical leadership are discussed. Although 'being ethical' is often discussed as a key component of leadership, the body of published research on the components of and practice of ethical leadership is actually smaller than expected, and research reviews demonstrate how it is studied and theorized in a way that is largely quantitative and positivistic. Research on ethical leaders tends to valorize them as inherently moral beings, while 'dark' or 'toxic' leaders exploit follower weaknesses for their own ends. The self-doubt associated with possessing 'neurotic' personality traits, for example, is seen as being inconsistent with being an ethical leader. Although there are accounts of leaders who overcome challenges and undergo personal transformation through 'crucible experiences,' less attention has been afforded to those who suffer guilt and shame as a result of their own moral failings and the organizational and social benefits which emerge from the process of recognizing one's moral failures. 
Next, it provides some detail on the concept of Moral Injury and its growth as a concept in the field of military studies and clinical psychology. Then the concept of Moral Recovery is introduced and Raymond C. Anderson's experience of recovery from Moral Injury through introducing environmentally progressive changes to the organization he founded (Interface Inc.) is outlined. Finally, as this model is primarily conceptual, the limitations of the model and avenues for future research are suggested.

\section{Reviews of Research on Ethical Leadership}

Ethics is often declared to be at the 'heart' of leadership, but only small amount of peer-reviewed research publications have been found at the intersection between the two fields (Ciulla 2014; Cullen 2018). Although there are numerous definitions of ethical leadership (Ko et al. 2018), Brown and Trevino's (2005) definition of ethical leadership is most frequently cited: "the demonstration of normatively appropriate conduct through personal actions and interpersonal relationships, and the promotion of such conduct to followers through two-way communication, reinforcement, and decision-making" (120).

Articles on ethical leadership often mention trends in the literature (Voegtlin 2016) but only a small number have attempted to systematically analyze this body of work. Brown and Trevino (2006) saw ethical leadership as an emerging concept and compared it to related approaches found in the literature on spiritual, transformative, and authentic leadership. They also identified two main sources of ethical leadership (situational antecedents and individual characteristics) and suggested a 16-point research agenda which urged further exploration of moral traits and practices, and the ethical behaviors of leaders, mentees, followers, and the context in which they worked. Bedi et al (2016) analyzed the literature on the outcomes of ethical leadership from the perspective of social learning and social exchange theory and found positive relationships between ethical leadership and an array of attitudes and behaviors. Ko et al (2018) reported that, despite the growth of interest in the field of leadership and ethics, ethical leadership studies remain a highly fragmented field. Like Brown and Trevino (2006) they also analyzed the literature on antecedents and individual characteristics, but also considered 'moderators' such as the characteristics of the leader, their followers, and the organizations they lead as well as relationships between leaders and followers, environmental situations, organizational cultures, workplace conditions, etc.

Ko et al (2018) note a tendency to use of survey instruments in the field of ethical leadership research (particularly Brown et al.'s [2005] ELS instrument). Commenting that the majority of empirical research has utilized convenience samples which primarily focused on middle managers as a unit of analysis they note that 'qualitative studies on ethical leadership are relatively scarce' and are primarily conceptual in nature which has resulted in 'limiting our knowledge of the application and longitudinal development of ethical leadership in authentic, real-life contexts' (126).

Finally, Lemoine et al's (2019) integrative review of ethical, authentic, and servant leadership unearths the connections of each style with distinct philosophical frameworks. Ethical leadership is grounded in deontological approaches and is concerned with complying with normative standards. Authentic leadership theory arises from Virtue Ethics and focuses on the leader's sense of self-awareness and self-concordance. Servant leadership is consequentialist and focuses on serving multiple stakeholders.

Like ethical leadership, its polar opposite, 'toxic' or destructive leadership has been primary studied from a positivistic perspective which attempts to identify certain leadership traits, behaviors, and personality types (Padilla et al. 2007; Pelletier 2010; de Vries 2014). Toxic leadership has been defined as 'leader behaviors leading to negative outcomes' (Yavas 2016) for organizations, followers, stakeholders, and society in general. Perhaps the key difference between studies of the dark and light side of leadership is based on how they research 'followership'; ethical leadership research tends to study the positive impact of that having a moral leader has on the work-lives and wellbeing of followers (Bedi et al. 2016), whereas studies of the followers of toxic leaders examine the reasons why individuals feel they must follow them (Tourish and Vatcha 2005; LipmanBlumen 2006; Thoroughgood et al. 2012).

This largely positivistic focus on (relatively) fixed traits and behavioral styles in the ethical and destructive leadership literature (Fraher 2016) may account for the limited amount of studies on processes of ethical change in organizations (Cullen, 2020). Alvesson and Einola (2019) have warned about the limitations of studying authentic, ethical, spiritual, and servant-based models as these approaches can result in depictions of leadership which are removed from the realities of contemporary organizational experiences. They advise against the contemporary trend of "excessive positivity in leadership studies' (383), which provide an overly simplistic picture of leadership in organizations.

One of Brown and Trevino's (2006) research propositions, for example, is that 'Neuroticism is negatively related to ethical leadership.'

Neuroticism reflects the leader's tendency to experience negative emotions such as anger, fear, and anxiety. Neurotic leaders are thin-skinned and hostile toward others. From a social learning standpoint, thin-skin and hostility are hardly the qualities that one associates with attractive and credible models. By con- 
trast, ethical leaders are exemplary models who care about and maintain positive relationships with their subordinates. Therefore, we propose that neuroticism is negatively related to ethical leadership (603).

The idea that leaders who experience 'negative emotional states' such as fear and anxiety are more likely to be unethical has been challenged by both popular and critical leadership scholarship. Popular accounts of leadership often discuss how it develops through overcoming significant challenges or obstacles. Studies variously discuss leadership as something learned through 'crucible' experiences: "intense, often traumatic, always unplanned experiences that had transformed them and had become the sources of their distinctive leadership abilities" (Bennis and Thomas 2002, p. 40). Mainstream accounts of the painful learning experiences of leaders are often framed as heroic narratives where the individual overcomes misfortune by channeling inner reserves of strength, resolve, or resilience.

Critical scholars such as Bell et al (2012), for example, applied William James' concepts of 'healthy-mindedness' and 'sick souls' (1906[1902]) to organizational contexts. 'Healthy mindedness' assumes a benevolent cosmological framework where individuals acknowledge the positive elements of life. People with 'sick souls,' on the other hand, are conscious that all is not well with the world and there is much to be fearful or anxious about. However, because sick souls acknowledge, and are aware of, the negative aspects of existence, they have a greater capability to be critical and to engage in initiatives to elicit change. James' perspective aligns with Freud's proposal that moral systems exist to assist people to develop and maintain social bonds, rather than acting on their instinctual selfish desires (Freud 1930/2001). Whereas Aristotle and the Virtue Ethicists propose that being ethical will lead to personal flourishing, James and Freud clarify that living an ethical life necessitates suffering (Lear 2015). Rather than seeing negative or 'sick' emotional states as incompatible with ethical leadership, James posits that they can facilitate critical thinking and pro-social change.

\section{Moral Injury}

The term 'Moral Injury' was coined by the psychiatrist, Jonathan Shay (1994, 2002, 2014) who spent decades working with traumatized Vietnam War veterans. Moral Injuries emerge when an individual commits an act that violates their deeply held moral values. These values can be so deeply held that the individual who violates them may not be aware that they have done so until the act has been committed. Strong, debilitating, feelings of guilt, shame, and anger can manifest for many years during the individuals experience of being morally injured. Shay based his original definition of MI (1994) on a combination of his patients' narratives and the representation of Achilles' story in Homer's Iliad.

Although the role of leaders is emphasized in Shay's work, other scholars point out that Moral Injuries can arise when individuals violate their own ethical codes by participating in or failing to prevent acts that transgress their value systems (Litz et al. 2009; Allen 2014). Unlike Post-Traumatic Stress Disorder (PTSD), which is often a response to exposure to terrifying incidents, Moral Injuries result from feelings of guilt and shame that arise after one has transgressed one's ethical norms (Alford 2016; Maguen and Litz nd). PTSD typically results from exposure to a traumatic experience and symptoms include aggression or hyperarousal ('a state of constant vigilance, the feeling that danger may strike at any moment' (Alford 2016), etc. Moral Injury results from 'knowing' that one has violated an important personal moral belief rather than 'witnessing' it and symptoms include a sense of a loss of meaningfulness and depression (Matthews 2014). Two examples of Moral Injury are discussed below and both of these refer to situations where individuals unintentionally violated communal moral frameworks that they were unaware that they shared, by following the instructions of others. Both morally injured individuals experienced guilt, shame, meaninglessness, and depression. These experiences differ significantly from the PTSD which typically results from a trauma experienced by an individual. PTSD involves re-experiencing the event through flashbacks and recurring dreams, avoidance of anything associated with the trauma, insomnia, and being easily startled or angered (van Velsen 2009). Clohessy and Ehlers (1999) study of ambulance service workers, for example, found that emergency services personnel can development PTSD as a result of exposure to traumatic incidents. Symptoms commonly experienced by these workers included intrusive memories (in $49 \%$ of the survey population), insomnia, and detachment from others. While PTSD is related to Moral Injury, Kalkman and Molendjjk (2019) point out that 'with the concept of moral injury, researchers generally do not aim to replace the concept of PTSD, but bring forward a concept that captures moral suffering' (4).

The development of the concept of the Moral Injury has introduced the idea that service personnel undergoing profound distress at what they may have done or witnessed, may not always be suffering from PTSD; they may also be experiencing ethical distress at a result of violating their moral framework. One of the key differences between Moral Injury and other forms of psychological trauma is the impact which it has on the character of the person experiencing it. Indeed, the sub-title of Shay's Achilles in Vietnam (1994) is 'Combat Trauma and the Undoing of Character.' In the introduction to the work, Shay states his principal concern in writing the work was 'to put before the public an understanding of the 
specific nature of catastrophic war experiences that not only case lifelong disabling psychiatric symptoms but can ruin good character' (xiii). The idea that character, as well as the psyche, can be traumatized or injured as a result of actions perceived, observed, or experienced that violate one's values is one that speaks directly to the practice of ethics.

It is important to differentiate between characters, as it is generally understood in psychological and ethical terms. According to Silverman and Byrne 'Psychoanalytically, character refers to a persons' habitual mode of overcoming inner conflict (or failure to do so) and the consequences this has for thinking, perceiving, and feeling about the world in addition to the way in which behavior is expressed overtly'(2009). Shay's discussion of character is based on understandings of the concept from moral philosophy which have been central to discussions of living ethically from Ancient Classical thought. Hall (2018) mentions that Aristotle used the word ethika to denote character. Aristotle wrote that individual character could be developed through the practice of virtues that eventually lead to a happy life through flourishing (Aristotle and Thomson 1976). The more we practice virtues (or vices) the greater the likelihood that they will become habits which constitute our character. Shay offers that what has been violated in cases like this is an awareness 'what's right,' or its Homeric equivalent, thémis. Carol Gilligan describes thémis as 'a sense of an inner moral compass we carry with us, which alerts us when we've lost our way or are doing something we know in our hearts is wrong' (2014, p. 92). Shay explains a violation of 'what's right' or thémis by referring to an incident in the first book of the Iliad where Achilles, the war hero, has his war prize (his beloved concubine Briseis) appropriated by his king Agamemnon. This violation of 'what's right' subsequently becomes a major incident for both characters story in the Iliad.

To demonstrate how character can be morally injured, two brief examples are shared. The first is from one of the earliest accounts provided in Shay's first book on the topic, Achilles in Vietnam (1994, pp. 3-4). A veteran recalled an experience during the Vietnam War where his unit received information from a Reconnaissance Patrol that three boats were unloading weapons in a bay. His unit opened fire on the boats but subsequently found out that they had killed unarmed civilians. Despite his senior officer's lack of concern for this fatal mistake, the veteran still felt 'deeply dishonored by the circumstances of its official award for killing unarmed civilians on an intelligence error' (4).

Because Moral Injuries result from the violation of ethical standards and values, rather than the direct experience of trauma, activities such as providing authorization to shoot enemies remotely (over radio communication, for example), the knowledge that one has played a role in a death from a distance can result in extreme distress (Conan 2012).
Matthews (2014) writes that little work has been done on the experiences of personnel who operate Unmanned Aerial Vehicles (Military Drones or UAVs). Press (2018) profiles a young man who came from a family with a proud military tradition, who chose to work for military contractors, particularly in the field of airborne image analysis. In his late 20s, the man suddenly underwent a physical and mental breakdown and was plagued with nightmares of being forced to watch innocent people being killed and maimed. Eventually, he completely re-evaluated his belief in the rationale for the counter-terrorist activities, the national security organizations and defense contractors who employed him, and indeed the logic of the military industrial context itself.

Although there has been a steady increase in the number of articles on Moral Injury, since the first was published in 2001, most are in the fields of military studies, psychiatric and clinical psychology. The majority of research work has been conducted on veterans and serving military personnel and those who provide support services to these. This is the first paper to discuss Moral Injury (and Moral Recovery) in the context of business ethics or ethical leadership.

\section{Moral Recovery}

'Our society lacks any real understanding of what's needed for purification after battle. We need rituals, we need liturgies, we need narratives, we need artworks that - and the point here is that it's not something you say to a veteran. "You, Mr. Veteran, you need to clean yourself up". It's that we all need to clean ourselves up after war. These people went on our behalf and in our name, and we need to purify as a community, not just as just say to this returning veteran "you need purification"” Shay In (Conan 2012).

Although there are many approaches to treating PTSD, Shay warns against 'medicalizing' recovery from Moral Injury and insists that 'recovery happens only in community'(Shay 2002) rather than on an individual basis. Alford (2016) suggests that attempts to medicalize Moral Injury is political; it places the injury at the level of the individual (the soldier) and not the senior officers and political leaders who put them in the situation where they were morally wounded in the first place.

Shay discusses the benefits of medical-psychological therapies to help veterans live with guilt, he also outlines how engagement with the arts and service is a way to restore the bonds which have been broken between the veteran and their communities. Shay (2014) writes that Moral Injury changes a person as follows: 'It deteriorates their character; their ideals, ambitions and attachments begin to change and shrink' (186). The final stage of recovery from these 
psychological injuries and restoring character and social trust involves addressing these elements through 'reconnecting with people, communities, ideals and ambitions' (Shay 2002, p. 168). In summary, Moral Recovery does not simply involved noticing that something has gone wrong ethically, and then fixing it. Instead, it involves engaging with the significance of what one has done, or allowed to happen, and subsequently working to create change that generates more sustainable and responsible benefits for societies, industries, and organizations.

Gerard (2020) proposes that this desire to make reparation can be amplified in care-based organizations such as those providing youth, education, or health services. It is not possible to completely resolve health and social problems, the resources required to do are often lacking. As a result of this orientation, a caring organization can exacerbate the extent to which individual workers (such as social workers and nurses) experience personal guilt for not being able to actually help people. This becomes generative of more guilt, which makes the employee work even harder and suffer greater levels of guilt, and as result 'compassion fatigue and burnout.' This article is not concerned guilt and reparation as repressed unconscious conditions, but rather with the effects on character of violating one's own moral frameworks. However, the article will later return to the idea of reparation as a concept which can contribute to the conceptualization of Moral Recovery.

An example of Moral Recovery is outlined below.

\section{Ray Anderson}

The key resource used for this section is Anderson's account of founding and running Interface Ltd, which is also a manifesto for businesses to lead the fight against the destruction of the natural world, Mid-Course Correction (1998). Although Anderson's account is often very honest about his emotional life, it cannot considered an autobiography. However, it offers some indications of his personal value system and entrepreneurial motivations.

Anderson, an industrial engineer, had worked for a major textile manufacturer in his native Georgia and had expected to rise to the top of the corporation. When he was passed over for promotion to the head of an operating division in his late 30s, he recounted feeling that this disappointment led him to begin on the path to realize his own entrepreneurial ambitions. He had been impressed with the carpet tile innovation pioneered by a company in the UK and developed a joint venture to bring the technology to the U.S. Following some initial teething problems, Anderson founded Interface in 1973 and in the following years it grew to be one of the largest producers of modular floor coverings in the world. In the prologue to Mid-Course Correction Anderson states that despite the company prospering beyond his expectations, that it experienced two significant setbacks. The first of these occurred in 1984 when office construction in the US collapsed as a result of a deep global recession. Interface diversified into renovations and other market segments and locations. The second challenge occurred in the early 1990s when the 'downsizing' trend impacted Interface's core markets. Anderson credits the company's survival to a dynamic new management team.

Anderson's experience of Moral Injury happened shortly after this. Just as Boltanski and Chiapello (2005) theorized how 'capitalism' sustains itself by absorbing and accommodating societal problems, particularly in the aftermath of crises, Carroll (1999) demonstrated that corporate social responsibility is an evolving concept which develops in line with societal concerns and expectations of business. Many theorists have tracked the emergence of a growing mainstream interest in environmental sustainability to the mid-1990s (Bell et al. 2012) which includes the corporate sector (Parr 2009; Cullen 2018). Interface's customers were no different and had begun to ask what the organization were doing for the natural environment. The research division of the company organized a task force made up of the company's international representatives to develop a response to this question. Anderson was invited to make an address to initiate the first meeting of the taskforce, and admits to not being initially interested in the question beyond the level of legal compliance.

In preparing to deliver this address, he read Paul Hawken's The Ecology of Commerce (1993) which details the huge amount of irreparable damage which industrial processes inflict on the natural world. Anderson described its impact as a life altering moment in injurious terms: "Hawken's message was a spear in my chest that is still there" (1993, p. 40). Anderson's description of the impact of this knowledge, and his investigations in the damage that his own company was doing to the natural world, are full of the language of sickness. For example, near the beginning of Mid-Course Correction he writes that learning the amount of material extracted from the earth "made me want to throw up" (p. 4).

Anderson's 'spear in the chest' analogy has been described by him and others (e.g., Bakan 2004) as an 'epiphany,' but this paper posits that it might be better described as a moral injury. Epiphanies are "sudden and abrupt insights and/or changes in perspective that transform the individual's concept of self and identity through the creation of new meaning in the individual's life" (McDonald 2007, p. 90). Epiphanies result in an individual changing their preexisting idea of who they are, or what their life means. "The experience of epiphany involves an often sudden realization by an individual that they have been living their lives according to a framework that has not served them or others 
well, and a shift to another which is more positive" (Bell et al. 2012, p. 190). Epiphanies, however, "are preceded by periods of anxiety, depression, and inner turmoil" (McDonald 2007, p. 98). Moral Injuries, on the other hand produce mental anguish rather than preceding it. Prior to his engagement with questions of what damage being done the natural environment by Interface's operations, Anderson initially "never 'gave a thought to what we were taking from the earth or doing to the earth in the making of our products" (Bakan 2004, p. 71).

MIs result from the unintentional violation of one's values. Anderson does not state what these values are, but shares brief personal insights. Although this information is too brief to give a detailed sketch of his moral system, Anderson makes some clear statements about his key experiences and learnings. For example, he clearly identifies one experience as a "defining moment" for him (p. 25). At the age of 13, his coach played him above his age in football practice and he suffered a head injury and decided to quit the sport. His coach phoned his father in work who found Anderson and castigated him for quitting. Although still hurting from the injury, Anderson returned to football practice and eventually secured a scholarship to college. Although he resented his father and hated his coach at the time, he later saw the lesson of never quitting despite setbacks as instrumental to his and Interface's success.

Throughout the text, he expresses distress at his own role in not being aware of the extent to which industrialists like him had externalized the damage done to the natural world; for example, "My God! Am I a thief too?" (p. 6). Anderson's father left school early to work to support his younger siblings through school and college and he describes this as a waste. However, Anderson felt that this awareness of intellectual waste made his father determined to ensure that his sons lives were not wasted and they all received college educations. Anderson often refers to Interface as his third 'child' through Mid-Course Correction. He sacrifices much for the company, including his marriage. His first spouse was strongly opposed to him leaving a steady job to set up Interface, and this disagreement eventually led to them divorcing. "In the midst of a heated argument with Sug one night, while the whole process was still unsettled, I stormed into an adjacent room and fell to the floor in abject anguish, wrestling with myself: To do it or not to do it? I got up form that floor and shouted aloud to no one but myself, 'By God! I'm going to do it!' It was the hardest decision of my life up to then" (pp. 34-35). Just as Anderson's father wished for his children to achieve their destiny, Anderson wished for his 'precious child,' for which he had sacrificed so much, to achieve its destiny.

This belief in destiny is reflected in his Anderson's realization that he had begun to reflect on the meaning his eventual retirement would have for him and Interface.
Later, I came to realize that it [Hawken's book] had touched me for another reason. At age 60, I was beginning to look ahead subconsciously to a day that would come soon enough when I would be looking back at the company I would be leaving behind. What would my creation, this third child of mine, be when it grew to maturity? I was looking, without realizing it, for that vision too. A child prodigy in its youth, would it become a virtuoso. What would that mean? These were and are strategically important questions to me, personally, as well to interface, Inc. - in the highest sense of the word, strategic. I'm talking about ultimate purpose. There is no more strategic issue than that (p. 40).

The reference to 'ultimate purpose' is a defining element of Moral Injury. While PTSD results in heightened anxiety and helplessness, one of the results of MI is loss of meaningfulness, or in Anderson's terms 'ultimate purpose.' However, the recovery path from MI also depends on restoring this meaningfulness, not just for oneself, but at an organizational and social level.

\section{Discussion}

Moral Injuries occur when individuals suffer as a result of their value system being violated as a result of something a leader or a person in legitimate authority has done or ordered, or, when an individual betrays their own values intentionally or unintentionally (Carey et al. 2016). It differs from PTSD in that it impacts on the individual's character, rather than on their psychological makeup. This paper proposes that Moral Recovery becomes possible when individuals work to create systems or organizational processes that help address the causes or source of their Moral Injury. The process of Moral Recovery shares some of aspects of reparation in that it consists of good work that makes amends with others we may have hurt (Hirschhorn 1988), but differs in how it attempts to alleviate guilt through changing a social system or practice, rather than making reparations with specific individuals, which Gerard (2020) articulates may ultimately sustain unhealthy work cultures without changing them. Indeed Gerard suggests that this can be changed by moving away from guilt (which is experienced at an individual level) to shared concern, which is a collective response to sharing moral and structural burdens.

However, 'shared concern' is not the same thing as organizational or systemic change. How then might the experience of recovering from a Moral Injury impact on a broader system? Ray Anderson helds an influential position in Interface and as the founder of his firm could design and implement a broad set of initiatives designed to impact on the 
organization strategy and operations, which then went on to influence the pro-environmental behaviors of staff at all levels in the firm (Bakan 2004; Werbach 2009). Other leaders may not have the same amount of 'centrality' or resources as Anderson who experienced his Moral Injury at a time of rising public and legislative concern about Climate Chance; Jagannathan and Rai (2017) demonstrate how a sense of a lack of time to question and discuss the ethics of a manufactured 'terrorist' crisis resulted in a killing with devastating effects on an officer who sought to prevent it, who then had deal with the emotional, organizational, and political implications that followed. Like Shay's army veterans the moral foundation of the officer was violated, so what options are available to him to introduce change to a system where broader societal and political discourses have warped the ethical environment in which he has found himself? Islam (2020) writes that psychological research on business ethics.

should examine how actors work within the spaces available to them and attempt to construct new spaces of action, balancing competing motivations to live within imperfect worlds, while shaping those words when moments of opportunity arise (2).

The police officer who resisted the 'cold blooded murder' (Jagannathan and Rai, 2017 p. 725) was side-lined, tacitly punished and transferred, yet perhaps the act of speaking of his experiences with academic researchers on his experience functions of as a way of working with the limited ethical space available. Islam (2020) comments that when the state sanctioned ideology changes to one that was based on right-wing nationalism, the ethical climate of the police force changed which made murder moral. In discussing his anguish at being unable to prevent the killing in an analysis that would later be published in an internationally regarded business ethics journal, he opened up a new space of action which challenged an emerging social doctrine.

The literature on Moral Injury has been written primarily from the perspective of care providers (particularly in the context of military services), psychiatrists and clinical psychologists. This article attempts to extend this literature beyond the field of military studies and demonstrate how Moral Recovery can initiate responsible organizational change, proactive environmental measures, and progressive social activities. In doing so, it attempts to make a contribution to the literature on ethical leadership which still has a largely positivistic and normative orientation.

However, there are a number of difficulties with bringing a concept developed in one research context into another. Shay's Moral Injury concept emerged from extensive practice-based fieldwork with veterans in one clinical locale. Finding similar cases in the business literature to test the idea that Moral Injuries might be 'cured' through adopting a form of proactive, extraordinary responsibility might prove difficult due to a lack of business leaders or managers willing to share distressing experiences or moments radical self-doubt. The example provided in this article is short and based entirely on secondary research materials. This approach is not uncommon in psychoanalytic theorizing or in non-medical conceptualizations of MI (Allen 2014; Hook 2018). Developing the concept in the context of ethical business and organizational leadership may prove to be a 'hard-to-reach' area due to the personal profiles of research participants, and institutional research ethics committees may understandably be unwilling to sanction research projects where individuals could be asked to reflect on painful experiences.

Secondary accounts where individuals discuss a reluctance to violate their own personal values (which they might not have been aware of at the time) may be a potential source of data. For example, Stieg Larsson is best known for being the best-selling author of the 'Millennium Trilogy' of novels: The Girl with the Dragon Tattoo (2005); The Girl Who Played with Fire (2006), and The Girl Who Kicked the Hornet's Nest (2007). Larsson died from a heart attack prior to the publication of the novels which then won international accolades, were a global commercial success and were adapted for the cinema in both Sweden and the US. Larrson was a prolific writer of fiction and journalism, and early in his career became active in a range of socially progressive and left-wing causes.

Following his death, Larsson's partner and friends recounted that much of his feminism had resulted from a Moral Injury in his mid-teenage years when he witnessed a 15-year-old girl being gang-raped by three of his friends at a camp site. Larsson did not help her despite her pleas to him (out of a sense of loyalty to his friends). He asked for her forgiveness some days later, which she refused. He was haunted by guilt as a result of his passivity for years and became an active advocate for social causes and against violence against women.

He established an organization which investigated racist and far-right extremist groups in his native Sweden and co-founded and edited its magazine, Expo until his death. Larsson became a committed feminist who used the Millennium Trilogy to raise awareness of the extent of misogyny in society. Throughout The Girl With the Dragon Tattoo, statistics about violence against women are printed in capital letters as a way to commence each section, such as ' $18 \%$ OF THE WOMEN IN SWEDEN HAVE AT ONE TIME BEEN THREATENED BY A MAN' (Thomas 2012). He named the central character of Millennium Trilogy' after the young girl he let down; Lizbeth.

Accounts of Moral Injury and Recovery such as Anderson's and Larsson's are uncommon, so additional cases are required to assist in the development of the concept in organizational cases. The difficult of accessing appropriate date 
may be overcome by analyzing other organizational ethical experiences, such as whistleblowing. Alford's groundbreaking study on whistleblowing, Whistleblowers: Broken Lives and Organizational Power (2001) asserts that whistleblowers recount five types of stories for why they spoke truth to power. The first of these narratives is "an imagination for consequences" (p. 66) for other individuals who have been or could impacted by the action they speak up for. In attempting to speak truth to protect others, they prevent Moral Injury.

This is not the only way in which accounts of the experience of whistleblowing are of utility in theorizing Moral Injury. More recently, Alford (2016) has written that whistleblowers, themselves, are examples of morally injured individuals. Alford's Whistleblowers (2001) challenges the myth of the heroic whistleblower who is rewarded and celebrated for their courage, and instead reports that many find themselves financially and professionally ruined. The impact on personal lives are often worse: "Most are in some way broken, unable to assimilate the experience, unable, that is, to come to terms with what they have learned about the world. Almost all say that they wouldn't do it again..." (p. 1). Whistleblowers, according to Alford (2016) are morally injured because they demonstrated naivety when speaking up because they believed that the world is, despite everything, just and moral. They are morally injured because they have been first-hand witnesses to the lack of a common moral narrative which they believed to be ubiquitous.

The idea that there is a largely shared common moral narrative or thémis provides another opportunity for exploring the concept of Moral Recovery. The latter years of the second decade of the twenty-first Century have seen a worrying rise in a form of populism in wealthy, liberal democratic states "which threatens undo what many considered long-delayed positive changes toward a kinder, more compassionate society" (Brenner 2018, p. 547). The result of the 2016 Presidential Election in the United States and the 'Brexit' referendum in the United Kingdom were often experienced as 'spears in the chest' to individuals. In late 2016, an op-ed in the New York Times asked if American's were experiencing collective trauma (Gross 2016), and the journal Psychoanalytic Dialogues invited its editorial board to report on their experiences as therapists and psychoanalysts with patients in direct aftermath of Trump's election as "for many of us, the current situation has felt even more disorienting and threatening" (Seligman et al. 2017, p. 112) than the $9 / 11$ attacks.

The election of Trump has been the discussed as a 'collective moral injury' (Brenner 2018) where beliefs about the goals of democracy and inclusion have been challenged by a form of populism which seeks to build walls, undermine the media, befriend tyrants, violate the natural environment, and normalize racism and misogyny. Trump's election has resurfaced traumas suffered by individuals; one of Corbett's (2017) patients commented that his bragging about groping women caused the trauma of her own experience of being sexually assaulted to re-emerge.

In a more general sense, the disquiet which has been felt by large proportions of populations in countries where farright or xenophobic parties have come to play some role in the government of their country is a form of collective moral injury. Alford (2016) refers to Primo Levi's discussion of why prisoners in Auschwitz experienced shame. Levi (1966) wrote that this stemmed from witnessing a crime and becoming remorseful because of a complete helplessness in being able to do anything about it. The fact that one is constrained and completely ill-equipped to do something about an atrocity that one is witnessing, and is a victim of, does not negate the knowledge that a wrong has still been done to another. The powerlessness felt by many in society helps may result in Moral Injury, but it also clarifies ones' individual values and more broadly shared moral frameworks. Carol Gilligan (2014) has outlined the many connections which she feels the MI concept is related to the 'ethic of care' which highlights the precedence of relationships over abstract normative moral precepts as determining our ethical choices (Gilligan 1982). Islam (2020) has outlined how psychology has the potential to make multi-level contributions to the study of business ethics and presented a multi-level framework that demonstrates the interplay between individual, interpersonal, and social systems which demonstrates that potential for individual processes to influence larger economic, social, or political discourses. Psychosocial and systems psychodynamics research, thus have a strong potential to contribute to further theorizing of how Moral Recovery might be enacted in organizations and this is discussed more in the Research Agenda section of this paper.

If the idea of Moral Injury, then, has become prevalent outside clinical settings, it is deserving of more studies in the context of the workplace, where the majority of adults spend most of their time. Many of the high-profile accounts of ethical failures in organizations include the voices of senior figures and employees who were morally injured as a result of what they had perceived happening in their organizations and these are likely sources of data which will lead to additional contributions to emerging theory in relation to ethical leadership theory. Alford (2016), for example, expresses concern about "the power of professionals to diagnose, categorize, and attach labels to people" (p. 13). This, of course is not new and significant management thinkers such as Henry Mintzberg (2004) and Sumantra Ghoshal (2005) warned of the dangers of teaching business students analyzing business organizations from the perspective an economized, disconnected rationality. Karen Ho's ethnography of investment banking practices on Wall Street, Liquidated (2009) 
provides a timely reminder, not just of the volatility that such thinking produces in markets, but of the instability it generates among workforces. Increasingly, theories have reiterated that Moral Recovery occurs through listening to the voices of the injured and developing cures at the level of community rather than the individual, suggests that recovery paths from moral injury must involve concrete ethical actions that require social and organizational activities to restore what has been broken and prevent such damage from happening again (Shay 1994; Shay 2002; Gilligan 2014; Shay 2014; Alford 2016; Brenner 2018). Although this has been well-researched in military psychology, there is a need to identify how it can effectively happen in non-military organizations.

Moral Injury has just begun to appear in papers submitted to management journals. Kalkman and Molendijk (2019) have highlighted the role that high-level organizational practices such as strategic ambiguity have in creating conditions which lead the moral disorientation at lower level employees which subsequently contributes to Moral Injury. Although this article addresses normative and positivistic models and theories of ethical leadership but proposing that distressing psychological experiences and ethical violations can produce pro-social and pro-environmental activities, it is important that future studies of Moral Recovery in the workplace incorporate critical approaches which are not overly celebratory of the 'crucible experiences' which Moral Injury can produce. For example, Stein (2016) theorized that trauma does not only produce of feelings of helplessness and anxiety, but can also generate over-optimistic 'fantasy of fusion' responses where 'intense fears of an enemy are replaced by the exaggerated embracing of it, in the absence of a more considered relation to it' (p. 932).

Discussing experiences of Moral Recovery is potentially a new way of exploring ethical leadership in a manner that differs from the majority of studies which assume that leaders are consciously ethical in their practices. Prior to his experience of being morally injured, there is no sense that Ray Anderson aligned his leadership practice with any of the theories outlined at the start of this article. This is not to say that he was in any way an unethical person, and it is likely that he (perhaps like most people) believed that he was living a moral life. However, the unexpected distress he felt at a relatively late stage of his success and career eventually resulted in some of the most pro-social, pro-environmental actions ever achieved by a single industrialist and the company he founded. Unlike ethical leadership theories which presume a conscious and deliberate moral practice on behalf of the leader, this article proposes that genuine ethical leadership can commence following the distressful realization that one has violated, or has been responsible for, the violation of moral frameworks that were previously hidden from oneself or others.

\section{Research Agenda}

The limitations of this conceptual paper point to a number of potential questions which might be asked to challenge and develop the contribution which the Moral Recovery concept might make to the ethical leadership literature.

1. There is a distinct lack of cases from the non-military (and especially business leadership) field. More examples of Moral Injury and Recovery are required to deepen investigation into the concept. In particular, research which differentiates between military and business leaders experience is required. Kalkar and Molendjik (2019) have recently proposed that there is more than one path to becoming morally injured and have called for more research on these, and on the various ways in which individuals cope with their injuries.

2. There is a strong need to understand the systemic nature of Moral Recovery. Kalkar and Molendjjk (2019) have demonstrated how border guards develop coping strategies when faced with Moral Injury. Some undertook 'undercover' humanitarian work to mitigate the poor treatment of migrants that was part of their orders. A key element of this work is to understand how organizational practices might create the conditions in which employees can be morally injured. These are not only limited to management practices such as 'strategic ambiguity' but can also relate to job design and HR procedures for helping employees. Nurses, social workers, police officers, educators, and clinicians have all been identified as occupations (Kalkman and Molendijk, 2019; Corley 2002) which are open to 'moral distress': a position where an individual is constrained from doing what is right by management directives, organizational policies, or legal instruments. Awareness of the ethically compromised environment of financial (Ho 2009) and 'Big Tech' firms (Zuboff 2019) continues to grow, but the experiences of lower level employees who must make decisions at the 'moral coalface' of such firms require more investigation. The impact of making decisions from a distance which will significantly impact the lives of people one does not know has been discussed above in relation to the pilots of military drones, but Ho (2009) and Taylor (2006) discuss the damage that making 'disconnected' investment decisions can have on communities, society, and employees alike. Content moderators at social media companies, for example, report experiencing personal distress as a result of the violent, racist, sexist, and abusive content that they have to review as part of their work (Hern 2018, 2019). More generally, middle managers and professionals frequently face having to make, or implement, decisions which violate their 
ethical norms as part of their employment conditions (Molinsky and Margolis 2005; Margolis and Molinsky 2008; Prottas 2013; Karanikola et al. 2014), and there are many opportunities to discuss how these occupational groups experience and navigate moral recovery that can help developed a more nuanced understanding of the process.

For example, psychosocial and systems psychodynamic approaches have been used to research the dissonance felt by nurses who experience anxiety as a result of their need to balance the provision of compassionate care and values with securing a professional position or meeting the requirements of senior management (Dashtipour et al. 2020; Wright et al. 2020). Systems psychodynamics is an approach which is based on open systems theory (which sees organizations as constantly changing eco-systems where norms and practices change in relation to the challenges that he organization faces in its own environment) and psychodynamic studies of organizations which applies concepts from psychoanalysis to understanding the unconscious forces that underpin what happens when groups of people try to work together to a (reasonably) shared goal. Indeed, psychosocial and psychodynamic approaches to studying organizations tend to think of them as being close to families with their bonds of love, resentments, and micro-aggressions (Casey 1999; Gabriel 1999). Petriglieri and Petriglieri (2020) identify the four key principles of research based on systems psychodynamics approaches as: 'a consideration of how unconscious forces affect human functioning, a focus on the interaction between individual and collective levels of analysis, a participative stance toward the production of theory and change in the field, and a subversive intent, both of the authority of detached scientists and that of repressive leaders and bureaucratic organisations' (pp. 413-414). Social research approaches based on psychoanalysis (such as Systems Psychodynamics or Psychosocial research) do not shy away from the more difficult areas of organizational life. Indeed guilt, conflict and anxiety are viewed and analyzed in a way that is both dispassionate and respectful of them when they arise in research processes. A leader does not suffer a moral would intentionally, but the act of attempting to understand the unconscious causes of their injury can shed light on the social, economic, or organizational discourses which caused them to transgress their own value system. When the harmful potential of these discourses are exposed, the leader can then take action to address them so they will not harm others.

3. In the absence of existing cases, and cognizant of the fact that researching Moral Injury and Recovery is difficult due to the personal and potentially sensitive nature of the disclosures required, new methodological innovations will be required. The concept of Moral Recovery may potentially be researched through secondary analysis of rich qualitative data used to research ethical issues in organizational contexts, such as whistleblowing.

4. The COVID-19 pandemic produced a variety of responses from political leaders, with some actively locking their countries down, others procrastinating, and some referring to pseudo-scientific theories and xenophobic reasoning. When faced with decisions by leaders which did not prioritize public health and welfare, communities actively bonded together in order to protect themselves and implement initiatives which sought to heal the damage done by irresponsible leaders. Research on the possibility of Moral Recovery at a societal level may be possible through analyzing the extent of social movements which resist the rise of extremist political parties and institutional passivity toward racism, antimigrant sentiment, sexism, and climate change denial (Foroughi et al. 2019; Just and Muhr 2019).

5. The response of organizations and leaders who have been disgraced or censured as a result of recent corporate scandals could be studied through the lens of Moral Recovery in order to deepen theoretical understandings of how the concept can be applied and understood in context.

6. The examples which are provided in this article (Anderson and Larrson) are male. There is a danger that the study of Moral Recovery may become mired in narratives of 'great men' who redeemed themselves through saving their organization morally. This can be addressed by exploring if and how the experience of Moral Recovery differs according to gender, race, ability, sexual identity or orientation, religious identity, etc.

Moral Recovery is a new theory in the business ethics and ethical leadership field, so nothing has been written about how to introduce it to students in leadership or business ethics classes. Like many psychodynamic ideas which have been applied in the various realms of business and organization studies, MI emerged as a concept used in psychoanalytic or therapeutic contexts. Although an array of psychoanalytic/psychodynamic theories have been applied in various organizational studies (Gabriel and Carr 2002; Gabriel 2016), only a very small proportion of these have been discussed in relation to management and business education and learning.

Taylor (2017) recalls a colleague informing him that a psychoanalytically oriented leadership development program in his institution had acquired two reputations: Some students enjoyed and engaged with it, but others resented 'looking inside' and expressed feeling that it was inappropriately intrusive. Clancy and Vince (2018) recount 
delivering a similar module and experiencing an angry and abusive response from a student which left the professor feeling attacked and brutalized. Asking students to engage with the unconscious, even in a way that will equipped them to handle the all-too-often unexplored emotional elements of organizational life, can often produce uncomfortable learning experiences that are resisted and inhibit learning. It goes without saying that students should not be asked to reflect on personal or familial experiences of being morally injured, as they are expressly concerned with the experience of being deeply traumatized.

In my teaching I briefly foreground the emergence of the theory from Shay's practice. It is rare to encounter anybody who is not aware of the strong critique which exists of attempts to glamourize the soldier's experience of war. Most generations have their anti-war movements, songs, plays and/or films, and the mainstreaming of critical analysis of contemporary warfare was one of the central logics of the Counter Culture movement of the 1960s. Although Shay's work contains graphic and horrifying accounts from morally injured veterans, he also provides us with a way to circumvent these details which have the potential to be upsetting to students. Shay used Homer's Iliad and Odyssey as a way to explicate to soldier's (and non-soldier's) traditional wisdom about the experience of being in war and returning to society, and what society needs to understand about the veteran's experiences. These myths are well known, colorful, and easily demonstrate the reality of war. The lessons of moral injury and its realities can be taught at a safe distance through an Homeric lens. The use of stories is important, as their key teachings are often easily remembered and accessed long after the student has graduated.

The greatest focus, however, should be given to highprofile business leadership examples, such as Ray Anderson, to help to explicate the ethical leadership context of discussing Moral Injuries. Students often share examples from that they have encountered in their reading of leaders they believe were morally injured. I have heretofore been reluctant to set assignments that would explore cases of Moral Injury as I believe that the focus of these should be on how the recovery process creates positive social and/ or environmental change. It is hoped that this article may stimulate the publication of these cases, as well as explorations of how they can be successfully taught in the leadership or business ethics class.

Acknowledgements The author wishes to express his gratitude to Chelsea Green publishers who are the distributors of the version of Mid-Course Correction cited in this article for their permission to use and quote from the text. He also wishes to thank Dr. Scott Taylor (University of Birmingham), Professor Amy Fraher (Southampton Business School), and to the anonymous reviewers for their advice and assistance in developing the paper.

\section{Compliance with Ethical Standards}

Conflict of interest The author declares that he has no conflict of interest.

Ethical Approval This article does not contain any studies with human participants performed by the author.

\section{References}

Alford, C. F. (2001). Whistleblowers: Broken lives and organizational power, Ithaca. London: Cornell University Press.

Alford, C. F. (2016). Depoloticizing moral injury. Journal of PsychoSocial Studies, 9(1), 7-19.

Allen, T. E. (2014). Life of Pi and the moral wound. Journal of the American Psychoanalytic Association, 62(6), 965-982.

Alvesson, M., \& Einola, K. (2019). Warning for excessive positivity: Authentic leadership and other traps in leadership studies. Leadership Quarterly, 30(4), 383-395.

Anderson, R. C. (1998). Mid-course correction: Toward a sustainable direction; the interface model. Atlanta: Peregrinzilla Press.

Aristotle \& Thomson, J. A. K. (1976) The ethics of Aristotle : the Nicomachean ethics, Revised ed./revised with notes and appendices by Hugh Tredennick. ed., Harmondsworth: Penguin.

Bakan, J. (2004). The corporation: The pathological pursuit of profit and power. London: Constable.

Bedi, A., Alpaslan, C. M., \& Green, S. (2016). A meta-analytic review of ethical leadership outcomes and moderators. Journal of Business Ethics, 139, 517-536.

Bell, E., Taylor, S., \& Driscoll, C. (2012). Varieties of organizational soul: The ethics of belief in organizations. Organization, 19(4), $425-439$.

Brown, M. E., \& Trevino, L. K. (2006). Ethical leadership: A review and future directions. Leadership Quarterly, 17(6), 595-616.

Brown, M. E., Trevino, L. K., \& Harrison, D. A. (2005). Ethical leadership: A social learning perspective for construct development and testing. Organizational Behavior and Human Decision Processes, 97(2), 117-134.

Bennis, W. G., \& Thomas, R. J. (2002). Crucibles of leadership. Harvard Business Review, 80(9), 39-45.

Boltanski, L., \& Chiapello, E. (2005). The new spirit of capitalism. London: Verso.

Brenner, G. H. (2018). Considering collective moral injury following the 2016 election. Contemporary Psychoanalysis, 53(4), 547-560.

Carey, L. B., Hodgson, T. J., Krikheli, L., Soh, R. Y., Armour, A. R., Singh, T. K., et al. (2016). Moral injury, spiritual care and the role of chaplains: An exploratory scoping review of literature and resources. Journal of Religion \& Health, 55(4), 1218-1245.

Carroll, A. B. (1999). Corporate social responsibility: Evolution of a definitional construct. Business \& Society, 38(3), 268-295.

Casey, C. (1999). "Come, Join Our Family”: Discipline and Integration in Corporate Organizational Culture. Human Relations, 52(2), $155-178$.

Ciula, J. (2014). Ethics: The heart of leadership. anta Barbara, CA: Praeger.

Clohessy, S., \& Ehlers, A. (1999). PTSD symptoms, response to intrusive memories and coping in ambulance service workers. British Journal of Clinical Psychology, 38, 251-265.

Corbett, K. (2017). Trump trauma. Psychoanalytic Dialogues, 27(2), $117-118$.

Conan, N. (2012). Moral Injury: The Psychological Wounds Of War. Talk of the Nation [podcast]. Retrieved January 24, 2019. 
Corley, M. C. (2002). Nurse moral distress: A proposed theory and research agenda. Nursing Ethics, 9(6), 636-650.

Cullen, J. G. (2018). Moral Injury \& Ethical Leadership. In International Studying Leadership Conference, Lancaster University.

Cullen, J. G. (2020). Varieties of responsible management learning: A review, typology and research agenda. Journal of Business Ethics, 162(4), 759-773.

Dashtipour, P., Frost, N., \& Traynor, M. (2020). The idealization of 'compassion' in trainee nurses' talk: A psychosocial focus group study. Human Relations, Forthcoming, 1-24.

de Vries, M. (2014). Coaching the toxic leader. Harvard Business Review, 92(4), 100.

Fraher, A. L. (2016). A toxic triangle of destructive leadership at Bristol Royal Infirmary: A study of organizational Munchausen syndrome by proxy. Leadership, 12(1), 34-52.

Foroughi, H., Gabriel, Y., \& Fotaki, M. (2019). Leadership in a post-truth era: A new narrative disorder? Leadership, 15(2), $135-151$.

Freud, S. (1930/2001). Civilization and its discontents. In Strachey, J. (Ed.) The Future of an Illusion, Civilization and its discontents and other works: The standard edition of the complete psychological works of Sigmund Freud. Vol XXI (pp. 64-145). London: Vintage/The Hogarth Press.

Gabriel, Y. (1999). Beyond Happy Families: A critical reevaluation of the control-resistance-identity triangle. Human Relations, 52(2), 179-203.

Gabriel, Y. (2016). Psychoanalysis and the study of organization. In R. Mir, H. Willmott, \& M. Greenwood (Eds.), The Routledge Companion to Philosophy in Organization Studies (pp. 212-225). Oxford: Routledge.

Gabriel, Y., \& Carr, A. (2002). Organizations, management and psychoanalysis: an overview. Journal of Managerial Psychology, 17(5), 348-365.

Ghoshal, S. (2005). Bad management theories are destroying good management practices. Academy of Management Learning \& Education, 4(1), 75-91.

Gerard, N. (2020). Reparation compulsion: Theorizing the pitfalls of guilt-driven labor. Organization Studies, 41(5), 621-639.

Gilligan, C. (1982). In a different voice: Psychological theory and women's development. Cambridge, Mass.: Harvard University Press.

Gilligan, C. (2014). Moral injury and the ethic of care: Reframing the conversation about differences. Journal of Social Philosophy, 45(1), 89-106.

Hall, E. A. (2018). Aristotle's way: How ancient wisdom can change your life. London: The Bodley Head.

Hawken, P. (1993). The ecology of commerce: A declaration of sustainability. New York, N.Y.: HarperCollins.

Hook, D. (2018). Melancholic psychosis-A Lacanian approach. Psychoanalytic Dialogues, 28(4), 466-480.

Hern, A. (2018). Facebook moderators tell of strict scrutiny and PTSD symptoms. The Guardian. Retrieved from January, 1, 2020, from https://www.theguardian.com/technology/2019/feb/26/facebookmoderators-tell-of-strict-scrutiny-and-ptsd-symptoms.

Hern, A. (2019). Revealed: catastrophic effects of working as a Facebook moderator. The Guardian. Retrieved from https://www.thegu ardian.com/technology/2019/sep/17/revealed-catastrophic-effec ts-working-facebook-moderator.

Hirschhorn, L. (1988). The workplace within. Cambridge: MIT Press.

Ho, K. Z. (2009). Liquidated: An ethnography of Wall Street. Durham: Duke University Press.

Islam, G. (2020). Psychology and business ethics: A multi-level research agenda. Journal of Business Ethics, 165(1), 1-13.

Jagannathan, S., \& Rai, R. (2017). Organizational wrongs, moral anger and the temporality of crisis. Journal of Business Ethics, 141(4), 709-730.
James, W. (1906). [1902]) The varieties of religious experience: A study in human nature. London: Longman.

Just, S. N., \& Muhr, S. L. (2019). "Together we rise": Collaboration and contestation as narrative drivers of the Women's March. Leadership, 15(2), 245-267.

Kalkman, J. P, \& Molendijk, T. (2019). The role of strategic ambiguity in moral injury: A case study of Dutch Border guards facing moral challenges. Journal of Management Inquiry, Forthcoming, 1-14.

Karanikola, M. N. K., Albarran, J. W., Drigo, E., Giannakopoulou, M., Kalafati, M., Mpouzika, M., et al. (2014). Moral distress, autonomy and nurse-physician collaboration among intensive care unit nurses in Italy. Journal of Nursing Management, 22(4), 472-484.

Ko, C., Ma, J. H., Bartnik, R., Haney, M. H., \& Kang, M. G. (2018). Ethical leadership: An integrative review and future research agenda. Ethics \& Behavior, 28(2), 104-132.

Lear, J. A. (2015). Freud (2nd ed.). Abingdon: Routledge.

Lemoine, G. J., Hartnell, C. A., \& Leroy, H. (2019). Taking stock of moral approaches to leadership: An integrative review of ethical, authentic, and servant leadership. Academy of Management Annals, 13(1), 148-187.

Levi, P. (1966). If this is a man, translated by Woolf, S., London: Bodley Head.

Lipman-Blumen, J. (2006). The allure of toxic leaders: why we follow destructive bosses and corrupt politicians and how we can survive them. Oxford: Oxford University Press.

Litz, B. T., Stein, N., Delaney, E., Lebowitz, L., Nash, W. P., Silva, C., \& Maguen, S. (2009). Moral injury and moral repair in war veterans: A preliminary model and intervention strategy. Clinical Psychology Review, 29(8), 695-706.

Maguen, S., \& Litz, B. (nd) Moral injury in the context of war. Retrieved January 24, 2019, from https://www.ptsd.va.gov/profe ssional/treat/cooccurring/moral_injury.asp.

Margolis, J. D., \& Molinsky, A. (2008). Navigating the bind of necessary evils: Psychological engagement and the production of interpersonally sensitive behavior. Academy of Management Journal, 51(5), 847-872.

Matthews, M. D. (2014). Stress among UAV Operators: Posttraumatic Stress Disorder, Existential Crisis, or Moral Injury? Ethics and Armed Forces: Controversies in Military Ethics \& Security Policy, l(1), 53-57.

McDonald, M. G. (2007). The nature of epiphanic experience. Journal of Humanistic Psychology, 48(1), 89-115.

Mintzberg, H. (2004). Managers not MBAs: A hard look at the soft practice of managing and management development. New Jersey: Pearson Education.

Molinsky, A., \& Margolis, J. (2005). Necessary evils and interpersonal sensitivity in organizations. Academy of Management Review, $30(2), 245-268$.

Parr, A. (2009). Hijacking sustainability, Cambridge, Mass. London: MIT.

Padilla, A., Hogan, R., \& Kaiser, R. B. (2007). The toxic triangle: Destructive leaders, susceptible followers, and conducive environments. Leadership Quarterly, 18(3), 176-194.

Pelletier, K. L. (2010). Leader toxicity: An empirical investigation of toxic behavior and rhetoric. Leadership, 6(4), 373-389.

Petriglieri, G., \& Petriglieri, J. L. (2020). the return of the oppressed: A systems psychodynamic approach to organization studies. Academy of Management Annals, 14(1), 411-449.

Press, E. (2018). The Wounds of the Drone Warrior. New York Times Sunday Magazine (June 17 2018), p. 30.

Prottas, D. J. (2013). Relationships Among Employee Perception of Their Manager's Behavioral Integrity, Moral Distress, and Employee Attitudes and Well-Being. Journal of Business Ethics, $113(1), 51-60$. 
Shay, J. (1994). Achilles in Vietnam: Combat trauma and the undoing of character. Oxford, New York: Maxwell Macmillan International, Atheneum.

Shay, J. (2002). Odysseus in America : combat trauma and the trials of homecoming. New York: Scribner.

Shay, J. (2014). Moral Injury. Psychoanalytic Psychology, 31(2), 182-191.

Silverman, D. K., \& Byrne, S. (2009). Character. In R. M. Skelton (Ed.), The Edinburgh international encyclopaedia of psychoanalysis (p. 79). Edinburgh: Edinburgh University Press.

Stein, M. (2016). Fantasy of fusion' as a response to trauma: European leaders and the origins of the Eurozone crisis. Organization Studies, 37(7), 919-937.

Taylor, S. (2017). Forming character in business school leadership education: Rejoinder to "The Development of Leader Character Through Crucible Moments". Journal of Management Education, 42(2), 301-305.

Taylor, M. (2006). Rationality and the ideology of disconnection. New York, Cambridge: Cambridge University Press.

Thomas, B. (2012). 'Kicking the hornet's nest: The rhetoric of social campaigning in Stieg Larsson's Millennium trilogy. Language and Literature, 21(3), 299-310.

Thoroughgood, C. N., Padilla, A., Hunter, S. T., \& Tate, B. W. (2012). The susceptible circle: A taxonomy of followers associated with destructive leadership. Leadership Quarterly, 23(5), 897-917.
Tourish, D., \& Vatcha, N. (2005). Charismatic Leadership and corporate cultism at Enron: The elimination of dissent, the promotion of conformity and organizational collapse. Leadership, 1(4), 455-480.

van Velsen, C. (2009). Post Traumatic Stress Disorder (PTSD). In R. M. Skelton (Ed.), The Edinburgh International Encyclopaedia of Psychoanlysis (p. 372). Edinburgh: Edinburgh University Press.

Voegtlin, C. (2016). What does it mean to be responsible? Addressing the missing responsibility dimension in ethical leadership research. Leadership, 12(5), 581-608.

Werbach, A. (2009). Strategy for sustainability: A business manifesto. Boston, London: Harvard Business School Press, McGraw-Hill.

Wright, A. L., Irving, G., \& Thevatas, K. S. (2020). Professional values and managerialist practices: Values work by nurses in the emergency department. Organization Studies, Forthcoming, 1-22.

Yavas, A. (2016). Sectoral differences in the perception of toxic leadership. Procedia: Social and Behavioral Sciences, 229, 267-276.

Zuboff, S. A. (2019). The age of surveillance capitalism: The fight for a human future at the new frontier of power. London: Profile Books.

Publisher's Note Springer Nature remains neutral with regard to jurisdictional claims in published maps and institutional affiliations. 